\title{
Better AIDS coverage
}

One of the basic roles of journalism is to inform people about what is happening. Technically, we describe this as the 'watchdog' role. But in Papua New Guinea the 'watchdog' has dangerously dosed off on the AIDS situation.

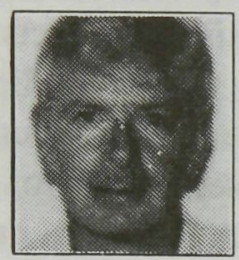

\section{By TREVOR CULLEN}

WHILE the media (television, newspapers and radio) does report on the AIDS situation in Papua New Guinea, there is a certain inconsistency in their coverage. News stories are limited to reporting the latest AIDS report or meeting. While this is essential and must be applauded, I think the media could do more, especially in the area of investigative journalism

One of the basic roles of journalism is to inform people about what is happening in the country on a national and regional level. Technically, we describe this as the 'watchdog' role. While I think the media in Papua New Guinea does an extremely good job providing the public with information despite many inherent limitations placed upon it - I think the 'watchdog' has dangerously dosed off on the AIDS situation.

Take Madang province as an example. I heard some months ago from two doctors working in the region that there are no HIV testing kits available or in use. What has happened to them? Will the health centres ever get them?

This alarming situation prompts further questions: Is this the same in other provinces? Is there any testing done in rural areas? How many people are trained to test? What percentage of samples are examined?

We need hard facts because there is serious confusion about the extent of HIV infection within the country. Health officials estimate more than 815 cases; the former Health Minister - after his visit to Uganda last year - spoke of between 6000 and 30,000 HIV cases in Papua New Guinea. Yet, a World Health Organisation report entitled Time to Act: The Pacific Response to HIV/AIDS predicts that for every HIV case in PNG, there could be 100 others.

Officially, Madang Province has only $15 \mathrm{HIV}$ cases. As journalists, can we 


\section{TREVOR CULLEN}

sit back and merely accept the official line and so continue to keep people in ignorance. There is no need to exaggerate or be sensational. What is required is a more updated and accurate analysis of the facts.

The public have a right to know about the potential seriousness of this situation. A journalist can investigate and expose the facts. If they are true, embarrassed officials will be forced to act.

And this is the most important role the media can play: to convince our political leaders and decision mak-

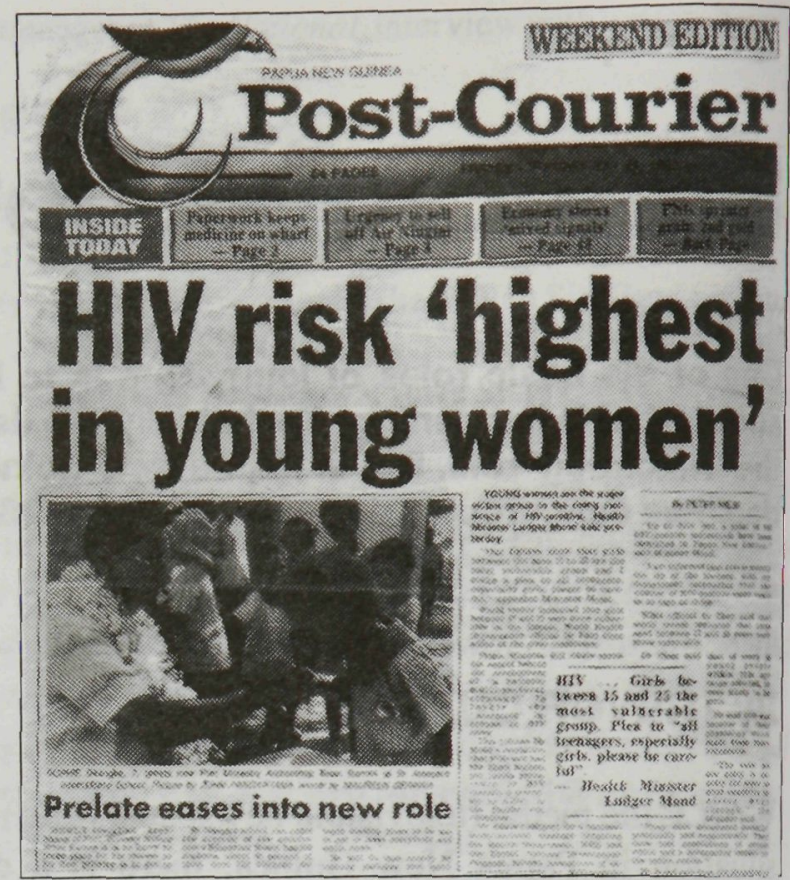

Post-Courier headline, 22 August 1997

ers that action needs to happen now. Through indepth reporting, journalists can challenge them to implement appropriate policies and programmes and so avoid the devastation and despair which occurred in other parts of the world because they did not act in time.

I talk from experience. Before coming to Papua New Guinea I worked in Malawi, a small country in southern Africa. When I first arrived, the country had no recorded HIV case. When I left ten years later, 22 per cent of the population - mainly 15 to 49-year-olds - were infected. Denial was the major factor why AIDS escalated out of control. It was only when people began to get sick in large numbers that the Government woke up. But it was too late. The silent plague had taken hold.

Tragically, PNG is still at the stage of denial and it is like watching a repeat performance of the Malawian situation in slow motion.

We all have a part to play to prevent another Malawian catastrophe. While politicians, churches, NGOs, health and education department can play a major role in speaking out, it is our trained journalists who can deliver the hard facts and shake us out of our frightening complacency. One way is to give AIDS a human face.

\section{Report the human side of the story}

Too many people in Papua New Guinea believe that AIDS has nothing to do 72 PACIFIC JOURNALISM REVIEW 4:1/1097 
with them. It is a disease of sinners, prostitutes, homosexuals, drug addicts. This attitude only promotes denial of the problem. Without knowledge people remain prejudiced, ignorant and powerless.

Public perception at the moment is that there is no real threat. When I questioned a number of students at Divine Word University about AIDS, a common response was that only prostitutes get AIDS. And one teacher remarked that Papua New Guinea does not have a problem because so few people have contracted the virus.

HIV/AIDS needs a human face in order to convince people. Journalists can do this by interviewing people infected with the HIV virus or who are suffering from the effects of full blown AIDS. Change their names and let them tell their story.

This demands from the journalist a high degree of resourcefulness and determination to get such people to speak. Confidentiality is vital. Yet, this type of story can have greater impact than lengthy factual reports because it shows how everyone is potentially at risk; it demolishes the myth that only certain people contract HIV/AIDS.

AIDS cases in Papua New Guinea reveal that the disease has affected all areas and social classes.

\section{Report in a way that promotes understanding rather than prejudice}

After many years of hearing that AIDS only affects certain groups and because many people in Papua New Guinea do not know anybody who has become sick with AIDS, the denial continues. Rather than finding out facts about AIDS and the types of behaviour which can put them at risk, people continue to blame others.

To challenge this misinformed perception, journalists can speak with, interview and write stories about people with HIV or AIDS; about how they became infected; the problems they have in dealing with the disease. Put a real face on the problem.

Finally, while the media is not on a AIDS crusade, it attracts large audiences and can offer invaluable information to help people in PNG overcome denial and possibly dying due to ignorance.

Fr Trevor Cullen, is Head of Journalism at Divine Word University in Madang, and an editorial board member of PJR. He was a guest speaker at a five-day AIDS awareness seminar in Port Moresby from 4-8 August 1997and is coordinatorof an HIV/AIDS media awareness advisory group. This article is an extract from his talk. 